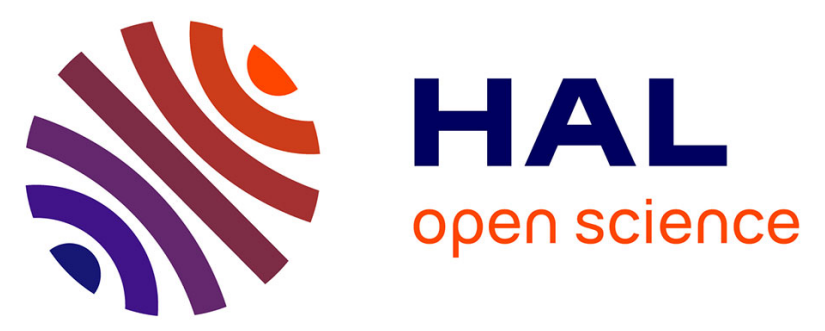

\title{
Hydraulic characterization of a karstic limestone vadose zone based on multi-methods geophysical measurements and lab testing
}

Clara Jodry, Céline Mallet, Jacques Deparis, Salma Ammor, Jean-Michel Baltassat, Mohamed Azaroual

\section{To cite this version:}

Clara Jodry, Céline Mallet, Jacques Deparis, Salma Ammor, Jean-Michel Baltassat, et al.. Hydraulic characterization of a karstic limestone vadose zone based on multi-methods geophysical measurements and lab testing. EGU General Assembly 2020, May 2020, Online, France. 10.5194/egusphere-egu20207213. hal-03554432

\author{
HAL Id: hal-03554432 \\ https://hal.science/hal-03554432
}

Submitted on 3 Feb 2022

HAL is a multi-disciplinary open access archive for the deposit and dissemination of scientific research documents, whether they are published or not. The documents may come from teaching and research institutions in France or abroad, or from public or private research centers.
L'archive ouverte pluridisciplinaire HAL, est destinée au dépôt et à la diffusion de documents scientifiques de niveau recherche, publiés ou non, émanant des établissements d'enseignement et de recherche français ou étrangers, des laboratoires publics ou privés.

\section{(c)(1)}

Distributed under a Creative Commons Attribution| 4.0 International License 
EGU2020-7213

https://doi.org/10.5194/egusphere-egu2020-7213

EGU General Assembly 2020

(c) Author(s) 2022. This work is distributed under

the Creative Commons Attribution 4.0 License.

\title{
Hydraulic characterization of a karstic limestone vadose zone based on multi-methods geophysical measurements and lab testing
}

\author{
Clara Jodry ${ }^{1}$, Céline Mallet ${ }^{1}$, Jacques Deparis ${ }^{2}$, Salma Ammor ${ }^{2}$, Jean-Michel Baltassat ${ }^{2}$, and \\ Mohamed Azaroual ${ }^{1,2}$ \\ 1Univ. Orléans, CNRS, BRGM, ISTO, UMR 7327, F-45071, Orléans, France (clara.jodry@cnrs-orleans.fr) \\ ${ }^{2}$ BRGM, Orléans, France
}

The vadose zone (VZ) is a highly heterogeneous and dynamic system that have a huge impact on fluid flows and heat transfer, from the soil to the saturated zone. In order to characterize flow patterns within the vadose zone, a comprehensive knowledge of spatial hydraulic parameters distribution is necessary. In this matter, geophysical techniques have proven to be efficient, providing various physical parameters and imaging of the underground. Nonetheless, these techniques are mainly used for water-saturated media and an appropriate calibration of the standard petrophysical relationships is necessary for VZ.

This study is carried out in the framework of the implementation, in an agricultural field, of the platform "Observatory of Transfers in the Vadose Zone" (O-ZNS, Centre - Val de Loire, France). The O-ZNS aims to understand and quantify mass and heat transfers in the VZ thanks to an exceptional well (depth $-20 \mathrm{~m}$ and diameter $-4 \mathrm{~m}$ ) associated with boreholes dedicated to geophysical measurements and instrumented piezometers. The emphasis is put on developing high-resolution investigations and focused monitoring techniques and sensors for the vadose zone. This observatory offers a unique support to study and establish the relationships to convert physical responses into hydraulic parameters, especially water content, in the VZ of a limestone aquifer.

The geophysical field investigations, conducted prior to the digging of the well, included various scales of observation with 3D Electrical Resistivity Imaging, 2D Magnetic Resonance tomography and crossholes Ground Penetrating Radar tomography. These highlighted three main lithological groups with a few meter-thick soil, a heterogeneous karstified limestone and a massive fractured limestone, all part of the same geological formation. The results put forth the importance of the karstified level heterogeneity on transfers' behaviour in the VZ, highlighting the presence of clay lens and a disparate water content distribution.

Going further, laboratory investigations have been carried out using field cores in order to characterize the VZ of the Beauce Limestone aquifer. Laboratory analyses enable us to establish Topp's, Archie's and CRIM (Complex Refractive Index Model) empirical relations and model. The objective now is to link quantitatively these geophysical field measurements, primarily electrical conductivity and dielectric permittivity, to the medium's hydraulic parameters (e.g., hydraulic 
conductivity, porosity, water content). Results from this analysis should bring valuable information on the hydrogeological behaviour of the aquifer system and underline the influence of the observation scales on the estimation of the hydraulic parameter values of the vadose zone. 